University of Nebraska - Lincoln

DigitalCommons@University of Nebraska - Lincoln

Faculty Publications: Department of Entomology

Entomology, Department of

1971

\title{
Hatching of Sod Webworm Eggs in Relation to Low and High Temperatures
}

Ellis L. Matheny

E. A. Heinrichs

Follow this and additional works at: https://digitalcommons.unl.edu/entomologyfacpub

Part of the Entomology Commons

This Article is brought to you for free and open access by the Entomology, Department of at

DigitalCommons@University of Nebraska - Lincoln. It has been accepted for inclusion in Faculty Publications:

Department of Entomology by an authorized administrator of DigitalCommons@University of Nebraska - Lincoln. 


\title{
Hatching of Sod Webworm ${ }^{1}$ Eggs in Relation to Low and High Temperatures ${ }^{2}$
}

\author{
Ellis L. Matheny ${ }^{3}$ and E. A. Heinrichs ${ }^{4}$ \\ Department of Agricultural Biology, University of Tennessee Agricultural Experiment Station, Knoxville, \\ Tennessee, USA
}

\begin{abstract}
Eggs of 12 species of sod webworm were exposed for various periods to temperatures of 0,10 , and $45^{\circ} \mathrm{C}$. Hatchability was compared with control eggs kept at $25^{\circ} \mathrm{C}$. Short exposures to any temperature did not significantly affect percent hatch. Prolonged exposure resulted in a significant decrease in hatchability for several species at $0^{\circ}$ and for all species at $45^{\circ} \mathrm{C}$. There was a significant difference in hatchability between the 3 generations of Crambus teterrellus (Zincken) and of Pediasia trisecta (Walker) at extreme temperatures. Populations of Agriphila ruricolella (Zeller), collected at 2 elevations, differed significantly in hatching percentage and developmental rate.
\end{abstract}

Sod webworm eggs are deposited in the thatch area of sod where they may be subjected to a wide range of temperatures. Eggs laid in spring and early fall may be exposed to near freezing or subfreezing temperatures at various locations in Tennessee (U.S. Department of Commerce 1969). Temperatures taken at the University of Tennessee indicate grass surface and sod thatch may exceed $45^{\circ} \mathrm{C}$ for several hours on mid-summer afternoons.

We have studied the effect of low temperatures on eggs of 3 sod webworm species (Heinrichs and Matheny 1969). Investigators working with other species have found that short exposures to low temperatures (Lindsay 1954, Watters 1966) and high temperatures (Guerra and Ouye 1968) did not affect hatch. However, high temperatures for longer durations significantly decreased percent hatch (Guerra and Ouye 1968), but the effect varied among the species tested. Data concerning the effect of high temperatures on sod webworm eggs are not available. 
This study was conducted to determine the response to high and low temperatures of eggs from: (1) various Crambinae species, (2) generations of the same species, and (3) populations of the same species collected at different elevations.

\section{Materials and Methods}

Eggs of 12 species of sod webworm were obtained from field-collected moths. Females were allowed to oviposit in plastic jelly cups ${ }^{5}$ held at room temperature. All eggs were less than 1 day old when tests were begun. There were 3 replicates of each treatment with 10 eggs/replicate. Eggs for each replicate were placed in desiccators and subjected to the following treatments: 0,10 , and $45^{\circ} \mathrm{C}$ temperatures for durations of $8 \mathrm{hr}, 1,2$, and 5 days, and then moved to $25^{\circ} \mathrm{C}$ to determine if development and hatching would occur. Exposure to the constant $45^{\circ} \mathrm{C}$ temperature for $1-5$ days is ecologically unrealistic. However, this exposure period was purposely used to provide sufficient stress to bring out physiological differences which might occur among species and between populations. High viability at $25^{\circ} \mathrm{C}$ in previous experiments was the criterion for selecting this temperature as a control. Eggs were examined daily to determine the effect of exposure temperatures on duration of hatch.

Saturated salt solutions (Winston and Bates 1960) were used to maintain desired relative humidities at each temperature in an attempt to keep the water-vapor pressure deficit (saturation deficiency) as small as possible (Table 1); therefore, all eggs were exposed to a similar degree of drying. Earlier workers (Buxton 1931, Evans 1934) noted the importance of expressing humidity in terms of saturation deficit and its role in governing mortality over a wide range of temperatures.

Table 1. Saturated salt solutions used to obtain desired water-vapor-pressure deficit at selected temperatures

\begin{tabular}{|c|c|c|c|c|c|}
\hline $\begin{array}{l}\text { Compound } \\
\mathrm{g} / 100 \mathrm{ml} \mathrm{H} \mathrm{H}_{2} \mathrm{O}\end{array}$ & $\begin{array}{c}\text { Temp } \\
{ }^{\circ} \mathrm{C}\end{array}$ & $\begin{array}{c}\% \\
\mathrm{RH} \\
\end{array}$ & $\begin{array}{c}\text { Actual } \\
\text { water-vapor } \\
\text { pressure } \\
(\mathrm{mm}-\mathrm{Hg}) \\
\end{array}$ & $\begin{array}{c}\text { Water-vapor } \\
\text { pressure } \\
(\mathrm{mm}-\mathrm{Hg}) \\
\text { at } 100 \% \mathrm{RH}\end{array}$ & $\begin{array}{c}\text { Water-vapor } \\
\text { pressure } \\
\text { deficit }\end{array}$ \\
\hline $39.12 \mathrm{NaCl}$ & $0^{\circ}$ & 75 & 3.44 & 4.58 & 1.14 \\
\hline $39.12 \mathrm{NaCl}$ & $10^{\circ}$ & 76.5 & 7.00 & 9.21 & 2.21 \\
\hline $56.70 \mathrm{KCl}$ & $25^{\circ}$ & 85 & 20.20 & 23.76 & 3.56 \\
\hline $24.10 \mathrm{~K}_{2} \mathrm{SO}_{4}$ & $45^{\circ}$ & 96 & 69.00 & 71.88 & 2.88 \\
\hline
\end{tabular}

Two species, Crambus teterrellus and Pediasia trisecta, occur simultaneously and throughout most of the summer in Knoxville, Tennessee. Light-trap records (Heinrichs and Matheny 1970) indicated each of these species may have 3 generations/year. The hatchability of these species was compared to determine whether the late spring and early fall generations might be more resistant to colder temperatures and the mid-summer generation more tolerant to heat.

Percent hatch and developmental rate of Agriphila ruricolella found in the Appalachian Mountains near Roan Mountain, Tennessee, (elevation 5,600 ft) were compared with $A$. 
ruricolella taken from Crossville, Tennessee, (elevation 2,000 ft). Development was determined by the following formula:

$\begin{gathered}\text { \% development } \\ \text { each exposure day } \\ \text { in relation to } \\ \text { development at } \\ \text { control }\left(25^{\circ}\right)\end{gathered}$
Mean days to
hatch at control
$\left(25^{\circ}\right)$$\quad \begin{gathered}\begin{array}{c}\text { Mean days to } \\ \text { hatch at control } \\ \left(25^{\circ}\right)\end{array} \\ \text { No. exposure days }\end{gathered} \quad \frac{100}{\text { (after exposure) }}$

\section{Results and Discussion}

\section{Species}

Table 2 indicates mean hatch of sod webworm species at each temperature (including all durations). Percent hatch at the control temperature $\left(25^{\circ} \mathrm{C}\right)$ was $96.7 \%$ or above in all species except Agriphila vulgivagella, Microcrambus elegans, and lst-generation C. teterrcllus, which had a percent hatch of $73.3,83.3$, and 90.0, respectively. High temperature $\left(45^{\circ} \mathrm{C}\right)$ including all durations resulted in a significant decrease in hatchability for all species. Only Crambus alboclavellus, M. elegans, and 1st- and 3rd-generation $P$. trisecta hatched significantly less at $0^{\circ}$ in comparison with 10 and $25^{\circ} \mathrm{C}$ temperatures. Thus, for most species of Crambinae whose eggs were studied, few significant differences were observed between percent hatch at 0,10 , and $25^{\circ} \mathrm{C}$.

Table 2. Mean percent hatch (including all durations) of Crambinae species at various temperatures ${ }^{\mathrm{a}}$

\begin{tabular}{lcccl}
\hline & Control & \multicolumn{3}{c}{ Exposure temperatures } \\
\cline { 3 - 5 } Species & temperature & & & \\
\cline { 3 - 5 } & $\left(25^{\circ} \mathrm{C}\right)$ & $\left(0{ }^{\circ} \mathrm{C}\right)$ & $\left(10^{\circ} \mathrm{C}\right)$ & $\left(45^{\circ} \mathrm{C}\right)$ \\
\hline Crambus albaclavellus Zeller & $96.7 \mathrm{abed}$ & $75.8 \mathrm{ghi}$ & $98.3 \mathrm{ab}$ & $38.3 \mathrm{klmno}$ \\
C. laqucatellus Clemens & $100.0 \mathrm{a}$ & $95.0 \mathrm{abcd}$ & $99.2 \mathrm{ab}$ & $49.2 \mathrm{jkl}$ \\
C. teterrellus (Zincken) 1st generation & $90.0 \mathrm{abcde}$ & $85.0 \mathrm{cdefgh}$ & $84.2 \mathrm{defgh}$ & $30.8 \mathrm{no}$ \\
C. teterrellus 2nd generation & $100.0 \mathrm{a}$ & $95.0 \mathrm{abcd}$ & $98.3 \mathrm{ab}$ & $50.8 \mathrm{j}$ \\
C. teterrellus 3rd generation & $100.0 \mathrm{a}$ & $99.2 \mathrm{ab}$ & $100.0 \mathrm{a}$ & $50.0 \mathrm{jk}$ \\
C. praefectellus (Zincken) & $100.0 \mathrm{a}$ & $95.8 \mathrm{abcd}$ & $95.0 \mathrm{abcd}$ & $33.3 \mathrm{mno}$ \\
C. pascuellus floridus Zeller & $96.7 \mathrm{abcd}$ & $86.7 \mathrm{bcdefg}$ & $90.8 \mathrm{abcde}$ & $37.5 \mathrm{lmno}$ \\
Pediasia trisecta (Walker) 1st generation & $100.0 \mathrm{a}$ & $76.7 \mathrm{fghi}$ & $100.0 \mathrm{a}$ & $30.0 \mathrm{no}$ \\
P. trisecta 2nd generation & $100.0 \mathrm{a}$ & $88.3 \mathrm{abedef}$ & $95.8 \mathrm{abcd}$ & $36.7 \mathrm{mno}$ \\
P. trisecta 3rd generation & $100.0 \mathrm{a}$ & $73.3 \mathrm{hi}$ & $97.5 \mathrm{abc}$ & $29.2 \mathrm{no}$ \\
P. mutabilis (Clemens) & $96.7 \mathrm{abcd}$ & $89.2 \mathrm{abcde}$ & $92.5 \mathrm{abcde}$ & $40.0 \mathrm{jklmn}$ \\
P. caliginosella (Clemens) & $100.0 \mathrm{a}$ & $90.0 \mathrm{abcde}$ & $95.0 \mathrm{abcd}$ & $38.3 \mathrm{klmno}$ \\
Microcrambus elegans (Clemens) & $83.3 \mathrm{efgh}$ & $13.3 \mathrm{p}$ & $80.8 \mathrm{efghi}$ & $26.7 \mathrm{o}$ \\
Agriphila ruricolella (Zeller) Roan Mt. & $96.7 \mathrm{abcd}$ & $90.0 \mathrm{abcde}$ & $88.3 \mathrm{abcdef}$ & $30.0 \mathrm{no}$ \\
A. ruricolella Crossville & $96.7 \mathrm{abcd}$ & $87.5 \mathrm{abcdefg}$ & $91.7 \mathrm{abcde}$ & $50.8 \mathrm{j}$ \\
A. vulgivagclla (Clemens) & $73.3 \mathrm{hi}$ & $69.2 \mathrm{i}$ & $71.7 \mathrm{i}$ & $45.0 \mathrm{jklm}$ \\
Chrysoteuchia topiaria (Zeller) & $96.7 \mathrm{abcd}$ & $96.7 \mathrm{abcd}$ & $95.8 \mathrm{abcd}$ & $39.2 \mathrm{jklmn}$ \\
\hline
\end{tabular}

aMeans followed by the same letter do not differ significantly at the $0.01 \%$ level of probability. 
Figure 1 shows total mean hatch for all species at all temperature and duration levels. Durations of $8 \mathrm{hr}$ (at all temperatures) did not significantly affect hatch. Increasing the exposure time, however, resulted in a sharp reduction in hatchability at $45^{\circ} \mathrm{C}$, the total hatch at 1,2 , and 5 days being $60.0,2.6$, and $0.2 \%$, respectively. Most eggs completely shriveled and collapsed after 2 days at $45^{\circ} \mathrm{C}$; only a single Pediasia caliginosella larva hatched after 5 days' exposure to this temperature. It appeared physically deformed and died shortly after being placed on a meridic diet.

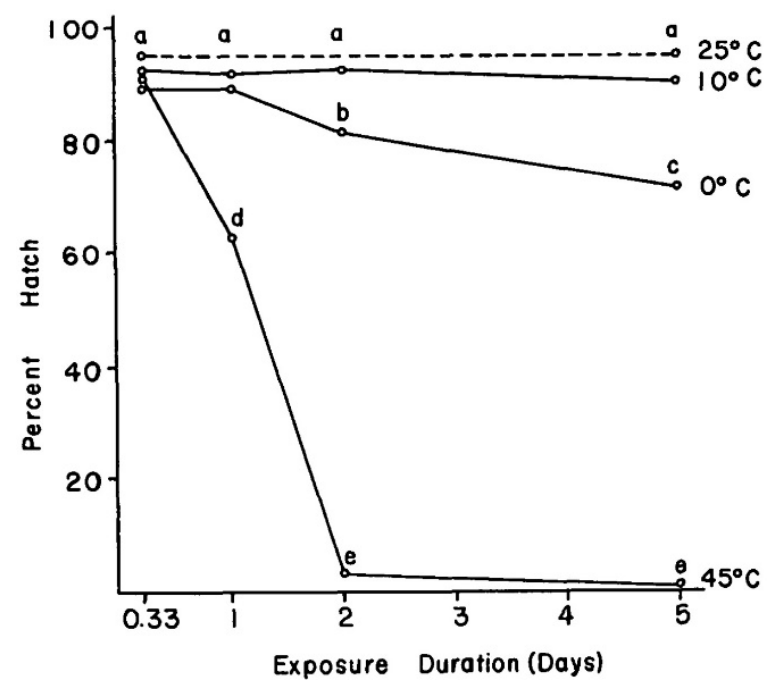

Figure 1. Total mean hatch for all species at all temperature and duration levels. (All points below the same letter do not differ significantly at the $0.01 \%$ level of probability.)

Prolonged exposure to $0^{\circ} \mathrm{C}$ temperatures ( 2 and 5 days) also resulted in significantly lower hatch than did the 10 and $25^{\circ} \mathrm{C}$ treatments (Fig. 1). There is a slight but nonsignificant decrease in egg hatch after 5 days' exposure to $10^{\circ} \mathrm{C}$. We (Heinrichs and Matheny 1969) have shown that longer exposure (30 days) at $10^{\circ} \mathrm{C}$ significantly lowered the hatch of sod webworm eggs.

\section{Generations}

The 3 generations of $C$. teterrellus and $P$. trisecta did not differ significantly in percent hatch at $25^{\circ} \mathrm{C}$ (Table 2). At 0 and $10^{\circ} \mathrm{C}$, lst-generation $C$. teterrellus had lower hatch than did succeeding generations. $P$. trisecta (1st and 3rd generations) had significantly lower hatch at $0^{\circ}$ than at $10^{\circ} \mathrm{C}$. Thus, these spring and fall generations are apparently no more cold tolerant than the 2nd (midsummer) generation.

According to Dr. A. B. Klots of the American Museum of Natural History in New York (personal communication), C. teterrellus is of neotropical origin whereas $P$. trisecta is essentially Boreal and closely related to Palearctic species. Therefore, it would be expected that $P$. trisecta eggs might be more resistant to cooler temperatures; but in this study, C. teterrellus eggs had better percent hatch at low temperatures than those of $P$. trisecta. Hatching 
percentage at $45^{\circ} \mathrm{C}$ indicated that $C$. teterrellus is also more heat tolerant than $P$. trisecta. Thus, eggs of $C$. teterrellus can withstand a wider range of temperatures at a similar saturation deficit.

\section{Populations}

Populations of Roan Mountain and Crossville A. ruricolella differed significantly in hatching percentage at $45^{\circ} \mathrm{C}$; the latter having a higher percentage hatch (Table 2). Significant differences in hatchability between the 2 populations did not occur at low temperatures. However, there was a significant difference in the effect of low temperature on developmental rate (Table 3). At 0 and $10^{\circ} \mathrm{C}$, daily development of Roan Mountain eggs ranged from 4 to $50 \%$ of that of the control $\left(25^{\circ}\right)$. Development of Crossville eggs ranged from 0 to $-35 \%$ of that of the control. In all except 1 treatment ( $10^{\circ}$ for 5 days) Crossville eggs exposed to low temperatures required more developmental days before hatching, after moving to $25^{\circ} \mathrm{C}$, than those placed directly in $25^{\circ}$ (control). Thus, development of Roan Mountain eggs was less severely affected by low temperatures. These eggs are, therefore, apparently more tolerant to low temperatures than eggs from Crossville moths.

Table 3. Mean days to hatch and daily percent development ${ }^{\text {a }}$ for $A$. ruricolella eggs after exposure to various temperature and duration levels

\begin{tabular}{|c|c|c|c|c|c|}
\hline Location & $\begin{array}{l}\text { Mean days } \\
\text { to hatch at } \\
\text { control }\left(25^{\circ}\right)\end{array}$ & $\begin{array}{l}\text { Exposure } \\
\text { temp }{ }^{\circ} \mathrm{C}\end{array}$ & $\begin{array}{l}\text { Exposure } \\
\text { duration } \\
\text { (days) }\end{array}$ & $\begin{array}{c}\text { Mean days } \\
\text { to hatch at } 25^{\circ} \\
\text { after exposure } \\
\text { period }\end{array}$ & $\begin{array}{l}\% \text { development }{ }^{\mathrm{b}} \\
\text { per exposure days } \\
\text { in relation to } \\
\text { control }\left(25^{\circ}\right)\end{array}$ \\
\hline \multirow[t]{7}{*}{ Roan Mountain } & 11.0 & 0 & 1 & 10.5 & $+50 a$ \\
\hline & & & 2 & 10.5 & $+25 \mathrm{abc}$ \\
\hline & & & 5 & 10.8 & $+4 \mathrm{bcd}$ \\
\hline & & 10 & 1 & 10.7 & $+30 a b$ \\
\hline & & & 2 & 10.5 & $+25 \mathrm{abc}$ \\
\hline & & & 5 & 9.5 & $+30 \mathrm{ab}$ \\
\hline & & 45 & 1 & 13.3 & $-230 \mathrm{f}$ \\
\hline \multirow[t]{8}{*}{ Crossville } & 10.5 & 0 & 1 & 10.8 & $-30 d$ \\
\hline & & & 2 & 11.2 & $-35 d$ \\
\hline & & & 5 & 10.7 & $-4 \mathrm{bcd}$ \\
\hline & & 10 & 1 & 10.7 & $-20 \mathrm{~cd}$ \\
\hline & & & 2 & 10.7 & $-10 \mathrm{bcd}$ \\
\hline & & & 5 & 10.5 & $0 \mathrm{bcd}$ \\
\hline & & 45 & 1 & 12.0 & $-150 \mathrm{e}$ \\
\hline & & & 2 & 13.0 & $-125 \mathrm{e}$ \\
\hline
\end{tabular}

aMeans followed by same letter do not differ significantly at the $0.01 \%$ level of probability. Data transformed to $(x+300)$.

$\mathrm{b}+=$ development during exposure period; $-=$ development delayed after return to control $\left(25^{\circ}\right)$ temperature;

$0=$ no development during exposure period

Development of Roan Mountain eggs was more severely affected by the $45^{\circ}$ temperature than the development of Crossville eggs. After exposure to $45^{\circ}$ for 1 day, development of Roan Mountain eggs was delayed 2.3 days, while development of Crossville eggs was 
delayed 1.5 days. In addition, no Roan Mountain eggs hatched after 2 days' exposure, while some of the Crossville eggs did hatch.

This study indicates that eggs of the 2 populations of $A$. ruricolella exhibit physiological differences in their response to extreme temperatures. In recent communication, Dr. A. B. Klots indicated that the adults of the 2 populations exhibit morphological differences and that they may be taxonomically distinct.

\section{Notes}

1. Lepidoptera: Pyralidae: Crambinae

2. Part of a thesis presented by the senior author in partial fulfillment of the requirements of the Ph.D. degree.

3. Assistant in Agricultural Biology, Department of Agricultural Biology, University of Tennessee Agricultural Experiment Station, Knoxville, Tennessee, USA.

4. Present address: University of Tennessee/Agency for International Development, Department of Agriculture, Seshadri Road, Bangalore 1, India.

5. No. 6916, Premium Plastics Co., 2440 S. Indiana Ave., Chicago, Illinois, USA.

Acknowledgments - We thank Dr. A. B. Klots of the American Museum of Natural History, New York, for identifying the sod webworm species and for valuable suggestions concerning the manuscript. The suggestions of Dr. T. L. Hopkins, Kansas State University, also are appreciated.

\section{References Cited}

Buxton, P. A. 1931. The law governing the loss of water from an insect. Proc. Entomol. Soc. London 6: 27-31.

Evans, A. C. 1934. Studies on the influence of the environment on the sheep blow-fly Lucilia sericata Meig. I. The influence of temperature and humidity on the egg. Parasitology 26: 366-77.

Guerra, A. A., and M. T. Ouye. 1968. Hatch, larval development, and adult longevity of four lepidopterous species after thermal treatment of eggs. J. Econ. Entomol. 61: 14-16.

Heinrichs, E. A., and E. L. Matheny. 1969. Hatching of sod webworm eggs in relation to low temperatures. J. Econ. Entomol. 62: 1344-7.

Heinrichs, E. A., and E. L. Matheny. 1970. Sod webworm (Lepidoptera: Pyralidae: Crambinae) moths collected in light traps. J. Tenn. Acad. Sci. 45: 61-64.

Lindsay, I. E. 1954. Influence of temperature on embryonic development of the pale western cutworm, Agrotis orthogonia Morr. (Lepidoptera: Phalaenidae). Can. Entomol. 86: 557-61.

U.S. Department of Commerce. 1969. Climatological Data, Tennessee Annual Summary. 74: 145-53.

Watters, F. L. 1966. The effects of short exposure to sub-threshold temperatures on subsequent hatching and development of eggs of Tribolium confusum Duval (Coleoptera: Tenebrionidae). J. Stored Prod. Res. 2: 81-90.

Winston, P. W., and D. H. Bates. 1960. Saturated solutions for the control of humidity in biological research. Ecology 41: 232-7. 